\title{
SALT AND SOVEREIGNTY IN COLONIAL BURMA
}

\begin{abstract}
Across monsoon Asia, salt is of such vital necessity that controlling its production or supply has historically been connected to the establishment and expression of political authority. On the one hand, rulers maintained the allegiance of their subjects by ensuring their access to salt of suitable price and sufficient quantity. On the other hand, denying rebels their salt was a strategy of conquest and pacification, while salt's necessity meant it could reliably be taxed to raise state finances. This article first sets out this connection of salt and sovereignty, then examining it in the context of colonial Burma, a province of British India from its annexation until its 'divorce' in 1935 (effected in 1937), and thus subject to the Government of India's salt monopoly. Focussing on salt brings into view two aspects of the state (while also permitting analysis of 'Upper Burma', which remains rather marginal in the scholarly literature). First, the everyday state and quotidian practices constitutive of its sovereignty, which was negotiated and contested where indigenes were able to exploit the chinks in the state's administrative capacity and its knowledge deficits. Second, in turn, the lumpy topography of state power. The state not only failed to restrict salt production to the extent it desired (with the intention that indigenes would rely on imported salt, whose supply was easier to control and thus tax), but conceded to a highly complex fiscal administration, the variegations in which reflected the uneven distribution in state power - thicker in the delta and thinnest in the uplands.
\end{abstract}

Q: What is the meaning of namak halal and namak haram?

A: The person who eats its salt and speaks ill of the Sirkar (government or ruler) is namak haram. Namak halal is such as gives up his life for the sake of his protection and obeys his command.

Q: If a person were aware of another's design to stir up rebellion against his master, is the reporting of it to his master the duty of a namak halal or of a namak haram?

A: If he did not report it to his master he is namak haram. ${ }^{1}$

Across monsoon Asia, where the climate is hot and humid and vegetable diets low in sodium (compared to those incorporating red meat) are prevalent, salt, or namak in Hindustani, is even

\footnotetext{
${ }^{1}$ Excerpt from the trial for sedition of Maulvi Modin in Chitoor in 1839, IOR/F/4/1878, File 79787, cited in: Chandra Mallampalli, A Muslim Conspiracy in British India? Politics and Paranoia in the Early NineteenthCentury Deccan (Cambridge: Cambridge University Press, 2017), 200.
} 
more a need for human existence than elsewhere in the world. ${ }^{2}$ Where (sufficient) salt could not be produced locally, or where there was a preference for the salt of other places - for salt was not homogeneous, differing, for example, by the size of crystals, mineral composition, and thus flavour - trade networks of varying scales developed in necessity. ${ }^{3}$ Assam's import of salt from pre-colonial Bengal was of such magnitude as to be balanced by return traffic in slaves and bullion, continuing to head the list of the region's imports into the early nineteenth century, for instance. ${ }^{4}$ In eighteenth-century Bengal, imposts on salt boiling works were sufficiently valuable that rights to their collection could be sold as revenue farms, itself an example of the late Mughal 'commercialisation of royal power' as such 'perquisites of kingship' were farmed to magnates following negotiation between the two groups based not only on the transfer of cash but also ritualised gift exchange and other means of developing patrimonial links. ${ }^{5}$ The sale of such rights did not diminish so much as reconfigure a set of relationships forged by sovereign authority, however. The situation in China was similar. There, salt was valuable enough for the state to erect its monopoly and for private merchants to accumulate considerable wealth and wield (or even broker) commercial, political, and even cultural power or influence in consequence, as recently illuminated by Yulian Wu's study of the salt merchants of Huizhou, in Jiangnan, and their material culture and relationship to the Qing court. ${ }^{6}$ In eighteenth-century India and China, therefore, mutually beneficial court-merchant networks served to enrich both groups, each trying to sustain and develop its fruitful connection to the other through material

\footnotetext{
${ }^{2}$ Mark Kurlansky, Salt. A World History (London: Vintage, 2003).

${ }^{3}$ Sameetah Agha, 'Trans-Indus Salt. Objects, Resistance, and Violence in the North-West Frontier of British India' in Lipokmar Dzüvichü and Manjeet Baruah, eds., Objects and Frontiers in Modern Asia. Between the Mekong and the Indus (London: Routledge, 2019), 25.

4 Jayeeta Sharma, Empire's Garden. Assam and the Making of India (Durham, N.C.: Duke University Press, 2011), 56.

${ }^{5}$ C. A. Bayly, Rulers, Townsmen and Bazaars. North Indian Society in the Age of British Expansion 1770-1870 (Oxford: Oxford University Press, 1983), 460-61. On the politics of gift exchange in South Asia during the colonial transition: Margot Finn, 'Material Turns in British History: II. Corruption: Imperial Power, Princely Politics and Gifts Gone Rogue', Transactions of the Royal Historical Society, vol. 29 (2019), 1-25.

${ }^{6}$ Yulian Wu, Luxurious Networks. Salt Merchants, Status, and Statecraft in Eighteenth-Century China (Stanford: Stanford University Press, 2017).
} 
and personal relations, blurring the simple dichotomies between sovereign and subject, and between duties and rights, thereby.

Within such context, the entry of servants of the East India Company into the salt trade of pre-colonial Bengal was seen as especially transgressive, for such 'objects [were] endowed with distinctive value and signs of the rulers' substantive authority', so that by 'making them available to merchants and agents (gumashtas),' Sudipta Sen has forcefully argued, 'the Company was disrupting the hierarchy of goods in the marketplace which marked the [...] order of things that related cultivator to agent, agent to trader, and trader to ruler.' ${ }^{7}$ Upon the prohibition of East India Company servants' participation in inland trade following the conquest of Bengal in 1765, Robert Clive, as Governor of Bengal, formed a private monopoly for the trade of salt (as well as betel and tobacco) constituted of Company servants 'on the ground' on the subcontinent as shareholders in compensation for the loss of their erstwhile trading privileges. ${ }^{8}$ Unhappiness with this arrangement among the Court of Directors in London led, first, to efforts to establish an excise duty and, then, under Warren Hastings, the transfer of the monopoly to the Company itself. Both operations failed due to the corruption of Company servants resulting, furthermore, in the exploitation of manufacturers, distortion of trade, and the violent fluctuation of prices. Eventually, the Company state inaugurated the Agency system, whereby each Agency provided advances to finance production (which had been necessary in earlier times, too) in their respective domains, receiving the outturn of salt, which was stored in government godowns and sold at set prices to private merchants in possession of licenses for inland trade. This system more or less survived in Bengal - even after the cessation of the Company Raj following the Mutiny-Rebellion of 1857-58 - until it

\footnotetext{
${ }^{7}$ Sudipta Sen, Empire of Free Trade. The East India Company and the Making of the Colonial Marketplace (Philadelphia: University of Pennsylvania Press, 1998), 82.

${ }^{8}$ In fact, Sen goes as far as to say that '[r]eading contemporary Company records of the conflict and debate over internal trade makes one wonder whether the East India Company conducted a war with the ruler of Bengal simply over salt, betel nuts, and tobacco' - op. cit., 82, and 82-87 for discussion of the Company's subsequent actions.
} 
was rendered obsolete by competition from foreign salt in the $1860 \mathrm{~s} .{ }^{9}$ The 1882 Indian Salt Act, discussed in what follows, enforced the government's monopoly over the collection, manufacture, and taxation of salt.

Being a necessity, salt was one of the few articles of consumption that could be effectively taxed to raise sufficient revenues all across the Indian subcontinent, the other significant article being a narcotic substance - opium. This was the (controversial) rationale for colonial taxation of salt which, ultimately, stood alongside the land tax as one of the pillars of the state's fiscal might and the Indian Empire built upon its foundations. Elsewhere from Bengal, salt continued to be manufactured from the sea (as in Bombay and Madras), from salt wells or saline springs and lakes (Rajasthan), or from salt mines (Punjab). There was no uniform rate of taxation, therefore, even though the state retained a monopoly over all domestic production, much as it did in Bengal. The state's only other monopoly - tellingly, once again - was opium. ${ }^{10}$ Bipan Chandra highlighted, over a half-century ago, that salt was the second most important source of revenue to the Government of India, 1880-1905. ${ }^{11}$ The combination of monopoly and taxation of salt thus served to enrich the government and, according to the Indian 'economic nationalists' of the late nineteenth century critical of colonial political economy, pressed on consumers, not least the masses of the Indian labouring poor whose needs were perhaps the greatest. That the state vigorously defended its monopoly, erecting an actual material barrier - variously of thorny shrubs, stone walls, and ditches - defended by officers as a customs preventive line, only served to confirm suspicions of the disregard for the needs of Indians. ${ }^{12}$

\footnotetext{
${ }^{9}$ A.M. Serajuddin, 'The Salt Monopoly of the East India Company's Government in Bengal', Journal of the Economic and Social History of the Orient, vol. 21, no. 3 (1978), 304-22, here the discussion has drawn especially on 304-08.

${ }^{10}$ Agha, 'Trans-Indus Salt', 22.

${ }^{11}$ Bipan Chandra, The Rise and Growth of Economic Nationalism in India. Economic Policies of Indian National Leadership, 1880-1905 (New Delhi: People's Publishing House, 1969), here 534, and up to 549 for scrutiny of salt taxation and the analysis of the nationalist critique thereof.

${ }^{12}$ Agha, 'Trans-Indus Salt', 23.
} 
Salt, then, is not such an unlikely focal point for the investigation of political sovereignty. In fact, as the epigraph to this article (extracted from a judicial case of 1839) demonstrates, namak was conjoined with the Islamic concepts of haram (proscribed) and halal (permitted) to capture the essential nature of political society in pre-colonial and colonial South Asia, these phrases still used today. ${ }^{13}$ Namak halal ('good salt') 'signified the allegiance owed to a king on the basis of having received the king's gifts of land, official titles, or other forms of patronage', Chandra Mallampalli notes, and 'was a reciprocal bond based on the exchange of gifts for loyalty.' Namak haram ('bad salt'), however, 'meant betrayal or treason committed by those who "ate the salt" of the ruler." ${ }^{14}$ Subversion of this conception of namak harami into an act of resistance to colonialism was made manifest by Gandhi's famous salt satyagraha of 1930. The salt monopoly was a pillar of colonial rule, brought to critical attention by the economic nationalists several decades prior as an example of injustice and maladministration. There could be few better methods of contesting colonial power and its injustices, Gandhi realised, therefore, than to peacefully defy the salt monopoly by partaking in the manufacture of salt. The 240-mile march to the coast to produce salt in defiance of the 1882 Act, during which the Mahatma amassed followers willing to risk imprisonment, was predicated on the prior declaration of sovereignty and self-rule (purna swaraj) - an action that reflected Indians' feeling that the reciprocal bond of ruler and ruled had disintegrated. ${ }^{15}$

Until its 'divorce' from British India by legislation of 1935 (effected in 1937), Burma (Myanmar) was administered by the Government of India and was thus also a part of the larger British Empire. At the outset of colonial rule in Burma, following the ceding of Arakan to the

\footnotetext{
${ }^{13}$ Not least in consequence of Hrishikesh Mukherjee's 1973 smash hit Bollywood film, Namak Haraam.

${ }^{14}$ Chandra Mallampalli, A Muslim Conspiracy in British India? Politics and Paranoia in the Early NineteenthCentury Deccan (Cambridge: Cambridge University Press, 2017), citations from 24, and see also 198, 214.

${ }^{15}$ Suchitra, 'What Moves Masses: Dandi March as Communication Strategy' Economic and Political Weekly, vol. 30, no. 14 (1995), 743-46.

Note that the finance minister of the new, independent Republic in 1947 likewise found it difficult to rationalise - on economic grounds - the abolition of the highly emotively-charged issue of the salt tax, in spite of M.K. Gandhi's pleas; see: Rakesh Ankit, 'Dr John Matthai (1886-1959): Between "Bombay Plan" and "Planning Commission"' Contemporary South Asia (forthcoming, 2020).
} 
East India Company in 1826 and its absorption into the Bengal Presidency, an administration was rolled out along the lines of the zamindari system operative in neighbouring Bengal, soliciting from prospective purchasers of the land details of the sum they would be prepared to pay annually to the state, as well as the amount of salt they would deliver to the government. ${ }^{16}$ In other words, salt was not only a commodity of local production in Arakan, but part of the appropriation by the new sovereign authority along similar lines as in Company India at large. In turn, after annexation of additional territory following the Second Anglo-Burmese War (1852-53) and the resultant constitution of 'Lower Burma' as a unit within British India, the transition from Company to Crown rule in 1858, the promulgation of the 1882 Act, and the final war with the Konbaung dynasty of 1885 , Burma and its inhabitants were subject to the Government of India's salt monopoly. In this article, therefore, the imperative to understand (colonial) Burma on its own terms, free from the baggage deriving from its categorisation either as part of South Asia or of Southeast Asia, on the one hand, is balanced with the fact that it was a frequently distinctive yet constituent part of the Indian Empire, on the other. ${ }^{17}$ How, it asks, did the Government of India's monopoly work in practice in Burma? And, reflexively, what does analysis of the administration of salt revenues reveal about the state in colonial Burma and of British imperialism?

\section{I}

A half-century of colonial rule transformed the economy of the 'wet zone' from a backwater of the Konbaung polity to one the world's largest rice producing and exporting regions. This was driven by the dramatic outward expansion of the rice frontier (as land in the Irrawaddy delta was turned to paddy), supported by the massive migration of Indians and the inhabitants

\footnotetext{
${ }^{16}$ Parimal Ghosh, Brave Men of the Hills. Resistance and Rebellion in Burma, 1825-1932 (London: Hurst \& Company/New Delhi: Manohar, 2000), 32.

${ }^{17}$ Jonathan Saha, 'Is it in India? Colonial Burma as a 'Problem' in South Asian History' South Asian History and Culture, vol. 7, no. 1 (2016), 23-29.
} 
of the Burma 'dry zone', themselves tremendous ecological and demographic changes that would later produce social tension and spur a nationalist movement into being. ${ }^{18}$ Thus, scholarly attention has fixed especially on what the British called Lower Burma, where this drama unfolded: foundational work by the erstwhile colonial civil servant J.S. Furnivall on colonial policy and political economy published in the second-quarter of the twentieth century, for example, was followed by a burst of scholarship in the 1970s by Michael Adas, Ian Brown, and James C. Scott, among others, the latter two scholars considering the connection of colonial policy to hardship and popular uprising - of which the most momentous episode was the Hsaya San Rebellion of 1930-32. ${ }^{19}$ The present century has seen another wave of interest, reflected, for instance, in scholarly works for a wider audience by Thant Myint-U and Michael Charney that situate British Burma in its precolonial context or contemporary Burma in its colonial context, respectively. ${ }^{20}$ The new generation of scholars of colonial Burma have diversified the field of inquiry yet further: Ashley Wright has examined the formulation of a racialised opium policy in tune with the exigencies of labour on the delta, while Jonathan Saha has argued that official misconduct (corruption) on the delta supported colonial rule around the turn of the century. ${ }^{21}$ Myanmar's 'democratic transition' since 2010 has eased foreign scholars' access to its archives and libraries, resulting in a recent uptick in historical production that has ranged from the study of cosmopolitanism and the 'religious economy' in which Islam and Buddhism

\footnotetext{
${ }^{18}$ Michael Adas, The Burma Delta. Economic Development and Social Change on an Asian Rice Frontier, 18521941 (Madison: University of Wisconsin Press, 1974).

19 J. S. Furnivall, Colonial Policy and Practice. A Comparative Study of Burma and Netherlands India (Cambridge: Cambridge University Press, 1948); Idem, An Introduction to the Political Economy of Burma (Rangoon: Burma Book Club, 1931). See, most notably: Adas, The Burma Delta; James C. Scott, The Moral Economy of the Peasant (New Haven: Yale University Press, 1976); and Ian Brown, A Colonial Economy in Crisis. Burma's Rice Cultivators and the World Depression of the 1930s (London: Routledge Curzon, 2005), which represents a culmination of several decades' work on the subject and summarises the debate with James C. Scott.

${ }^{20}$ Thant Myint-U, The Making of Modern Burma (Cambridge: Cambridge University Press, 2001); Michael W. Charney, A History of Modern Burma (Cambridge: Cambridge University Press, 2009).

${ }^{21}$ Jonathan Saha, Law, Disorder and the Colonial State. Corruption in Burma c.1900 (Basingstoke: Palgrave Macmillan, 2013); Ashley Wright, Opium and Empire in Southeast Asia. Regulating Consumption in British Burma (Basingstoke: Palgrave Macmillan, 2014).
} 
'competed', to the texture of life in port cities such as Rangoon and the (post-)colonial state's efforts to 'improve' its urban environment. ${ }^{22}$

Figure 1

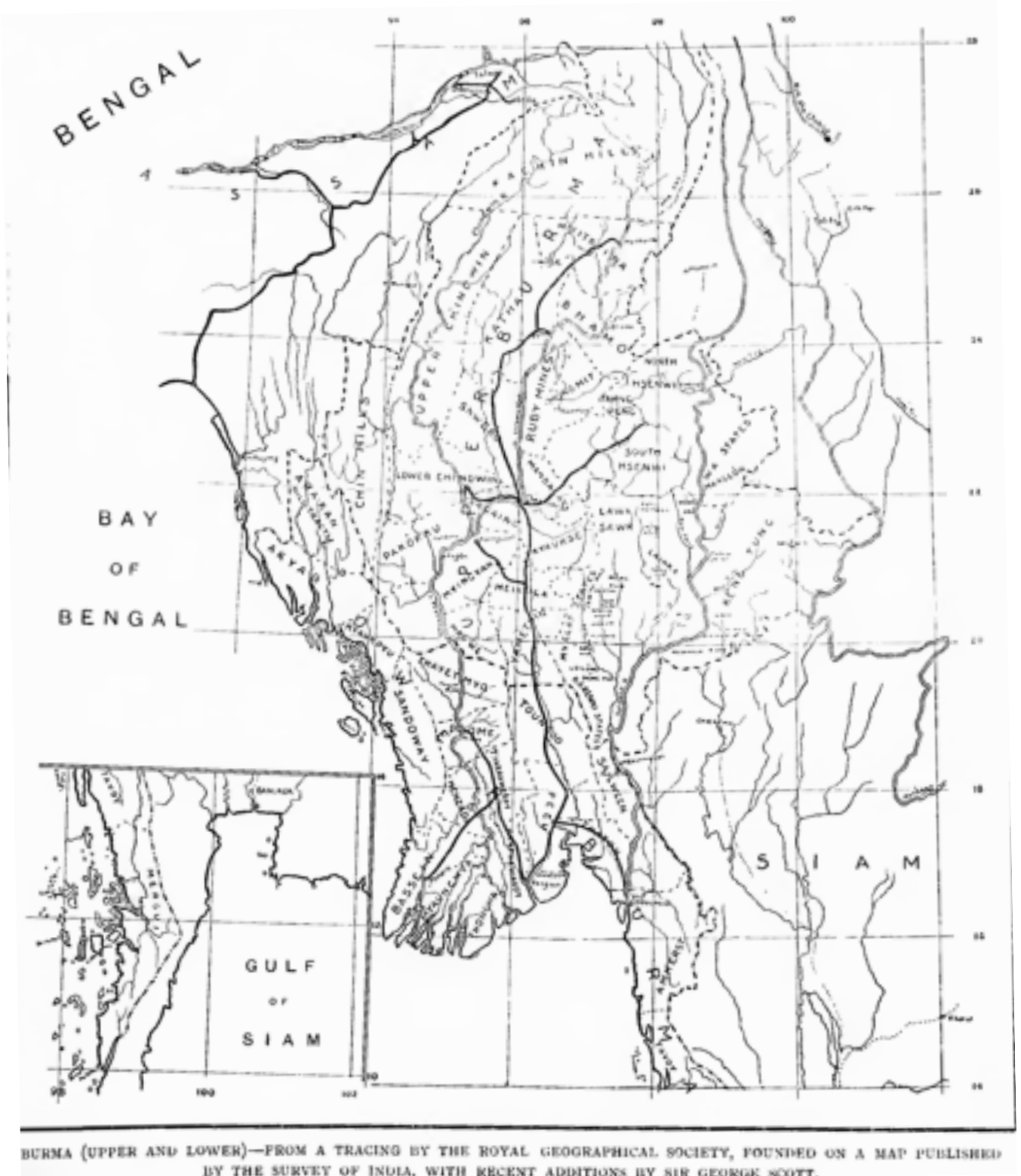

\section{Map of British Burma with the Divisions of Lower Burma, Upper Burma, and the Semi-Autonomous States $^{23}$}

\footnotetext{
${ }^{22}$ See, for instance: Michael Sugarman, 'Reclaiming Rangoon: (Post-)imperial Urbanism and Poverty, 1920-62' Modern Asian Studies, vol. 52, no. 6 (2018), 1856-87; Su Lin Lewis, Cities in Motion Urban Life and Cosmopolitanism in Southeast Asia, 1920-1940 (Cambridge: Cambridge University Press, 2016); Nile Green, 'Buddhism, Islam and the Religious Economy of Colonial Burma' Journal of Southeast Asian Studies, vol. 46, no. 2 (2015), 175-204.

${ }^{23}$ Extracted from: J. George Scott, Burma. A Handbook of Practical Information (London: Alexander Moring, 1906), 520. The author was an old Burma hand, at first variously a journalist and schoolmaster, then invited by the government in 1885 to assist with the establishment of the new colonial administration in Upper Burma,
} 
Somewhat removed from the drama of colonialism unfolding centre-stage in the delta region, the 'dry zone' and Upper Burma (Figure 1) at large have remained in the wings in each of these bursts of scholarly production, or else aspects of Upper Burma's history have featured as disconnected subplots. In fact, this vast space has long occupied a marginal place within the historiography of colonial Burma, studied insofar as it serves as the backdrop to the Third Anglo-Burmese War of 1885 that resulted in the defeat of the Court of Ava and the termination of rule by the Konbaung dynasty. ${ }^{24}$ Within this space, the borderland has received perhaps the least attention from historians of colonial Burma, save in connection with efforts to delineate the Burma-China frontier studied by a few scholars. ${ }^{25}$ Study of the colonial borderland has perhaps been hindered more than helped by the interest in 'Zomia' following publication of James Scott's now seminal The Art of Not Being Governed (2009), for it characterises this space as one where people escape the power of states and empires, even as the latter - as this article shows - strived ever harder to reach into and control. ${ }^{26}$ At the same time, the realities of life in much of Upper Burma - not least its remotest corners - has also problematised historical inquiry: not only the distance from Rangoon and the delta economy but also the relative isolation of its most significant industries (including the harvesting of teak from the forests or the mining of rubies and jade), not to mention the difficult terrain and lack of transport infrastructure away from the Irrawaddy, the sparseness of the population outside its few towns, and the thinness of the colonial administration in consequence. All this has resulted in a paucity

eventually rising to Deputy Commissioner of the colony, these experiences forming the substance of numerous publications.

${ }^{24}$ To take but one important example: Myint-U, Making of Modern Burma.

${ }^{25}$ For an elaboration of this point, see: Emily Whewell, 'Legal Mediators: British consuls in Tengyue (Western Yunnan) and the Burma-China Frontier Region' Modern Asian Studies, vol. 54, no. 1 (2020), 95-122, here, 97 and n. 4.

${ }^{26}$ James C. Scott, The Art of Not Being Governed: An Anarchist History of Upland Southeast Asia (New Haven: Yale University Press, 2009). The concept's significance and utility have been evaluated by a number of scholars, not least in the special issue on 'Zomia and beyond' in Journal of Global History, vol. 5, no. 2 (2010), 185-346. 
of historical material relating to Upper Burma in comparison to what is available for Lower Burma.

And, yet, because salt was a necessity to the populace and critically entangled with political sovereignty in monsoon Asia, it affords a novel lens through which to examine the relationship of colonial power to society and colonialism's embeddedness in everyday life across Burma. ${ }^{27}$ 'The quotidian history of state power in colonial contexts has attracted comparatively little attention, in Burma and beyond', Jonathan Saha writes, and it is toward this agenda that this article makes a contribution, focussing on the period from the passing of the salt legislation of 1882 and the final annexation of 1885 to the separation of Burma from India and the outbreak of war in the later $1930 \mathrm{~s} .{ }^{28}$ Such was its importance, the Government of India requested the extraction from Burma's revenue and trade reports those details relating to the salt revenues, which were duly published in a dedicated report from 1897-98, copies of which can be found in the India Office Records (IOR) at the British Library. ${ }^{29}$ The reports, along with records now housed in the National Archives of Myanmar (NAM), constitute the major bodies of sources consulted and incorporated into the analysis that follows, supplemented with a range of published materials, including travelogues and the administrative manuals written by (often, retired) Burma hands. ${ }^{30}$

The distinctive experience of colonialism in Burma offers, as Saha also advocates, considerable food for thought to historians of the Indian Empire who have largely neglected British Burma or else treated it as a passing curiosity. ${ }^{31}$ The opening of this article makes clear

\footnotetext{
${ }^{27}$ This article does not describe the nature of Burma's salt industry, its technologies, and so forth, in any detail, a forensic account and census of which in the various districts can be found in: IOR/V/27/324/24: R.M. Thurley, Note on the Salt Boiling Industry in Burma (Rangoon: Government Printing, 1908).

${ }^{28}$ Saha, Law, Disorder and the Colonial State, 4.

${ }^{29}$ IOR/V/24/3934: Report on the Administration of Salt Revenue in Burma for the Year 1897 (Rangoon: Government Printing, 1898), 1.

${ }^{30}$ Note that citations from sources from the NAM take the following format: government department, year, file number, accession number, page number. In the case of IOR materials, the full shelfmark precedes a short description of the item.

${ }^{31}$ Saha, 'Is it in India?', 23-29.
} 
the place of salt in the political economy of - and formulation of political authority in monsoon Asia, not least in defining the accord between ruler and ruled. The beginning of the next section develops this further, demonstrating the role played by the controlling of access to salt in the conquest and pacification of Upper Burma in ways typical of 'frontier expansion' elsewhere in British India, before attention shifts to the efforts to institute the Government of India's salt monopoly across Lower and Upper Burma. Whatever the value of the Burmese example to the work of South Asian historians, this should not lead us to suppose that Burma was in any way a uniform entity, in ways that the remainder of the article demonstrates. What is evident from the centre's consultations with its officers in the districts is the differences in knowledge and administrative capacity that impacted how deeply the government's representatives could reach into local society and how firmly the latter could be grasped. Because the compact between sovereign and subjects was so finely balanced, a fact revealed by the study of the salt administration, these variegations in the resources - epistemological, material, or of manpower - shaped the degree to which political authority could be contested from the bottom up. Borrowing from Lauren Benton's geographical analysis of law and sovereignty that draws attention to the challenges posed by oceans and islands, mountains and rivers to the establishment of imperial legal regimes, this article argues that the topography of colonial sovereignty and power in Burma was lumpy, thick in some places, particularly the delta region within Lower Burma, but thinner and more precarious in others, not least in Upper Burma. $^{32}$

\footnotetext{
${ }^{32}$ Lauren Benton, A Search for Sovereignty. Law and Geography in European Empires, 1400-1900 (Cambridge: Cambridge University Press, 2010). For recent work on south Asia that has taken up the gauntlet laid down by Benton, see: Elizabeth Kolsky, 'The Colonial Rule of Law and the Legal Regime of Exception: Frontier "Fanaticism" and State Violence in British India', American Historical Review, vol. 120, no. 4 (2015), 1218-46; Mark Condos, The Insecurity State. Punjab and the Making of Colonial power in British India (Cambridge: Cambridge University Press, 2017).
} 
Salt was as critical to the establishment of sovereignty as it was to its proper expression; integral, in fact, to the very processes of conquest and pacification. Salt had earlier been among the prize property - the 'legitimate confiscation' or loot - claimed once East India Company forces had scaled and entered Multan's city walls following the protracted siege of 1848-49, the centrepiece of the larger and last Anglo-Sikh conflict in Punjab which preceded the Second Anglo-Burmese War (1852-53) by but a few years, these two conflicts representing the Company state's burst of 'lateral expansion' out of its north Indian heartland. This salt-loot was later disposed of as a means of converting the cost of warfare into profit and reward. ${ }^{33}$ Victory in the 1848-49 war brought the borders of the Company state to area now known as the Northwest Frontier Province (or Khyber Pakhtunkhwa), which were home to the Kohat salt mines. These mines had not been monopolised in the immediate pre-colonial period by the Sikh rulers who claimed authority over the area, but instead were worked by local labour and remained largely under the control of local Afridi tribesmen, the salt taken to markets throughout the networks of caravan trade lacing north India (and central Asia) in the hands of Afghan pastoral-nomadic groups. ${ }^{34}$

After the conquest of Punjab from the Sikhs, the new Company regime tried to establish its authority over Kohat and control the output, taxation, and trade of its salt. For this, and wider interference in the lives of uplanders, they faced fierce resistance, resulting in a long period of 'pacification' from the 1840 s all along the Indo-Afghan frontier, instituted through punitive measures such as baramta (retaliatory seizure of animals, property, and persons) and bandish (blockades) if not through 'campaigns' into tribal territory. ${ }^{35}$ Afridis took control of the Khyber

\footnotetext{
${ }^{33}$ Punjab Archives and Library, Lahore, Political Department Proceedings, 10.11.1849, 3687-99. Margot C. Finn has lately examined the debates about the seizure and proper disposal of loot from the battlefield to later historical reflection, and thus the history of colonial looting as British historiography: 'Material Turns in British History: I. Loot' Transactions of the Royal Historical Society, vol. 28, no. 1 (2018), 5-32, here 15 onward.

${ }^{34}$ Agha, 'Trans-Indus Salt', especially 25-38. On the trade networks plied by Afghans in north India and central Eurasia: Jagjeet Lally, India and the Silk Roads (London: C. Hurst \& Co., 2020), chapter 4.

${ }^{35}$ Kolsky, 'Colonial Rule of Law', here 1224-25.
} 
Pass from the British during the cataclysmic 1897 uprising on the 'tribal frontier' - a humiliation for British imperialists witnessed by a young Winston Churchill - but only because, Sameetah Agha has found, their list of grievances submitted on the eve of their attack was not addressed. Among these complaints was the rate of salt tax, by 1897 a subject of contestation and negotiation for almost a half century. ${ }^{36}$

In 1885, the Court of Ava was vanquished in the Third Anglo-Burmese War; the British forces were led, somewhat significantly, by men with Punjab experience in many cases. ${ }^{37}$ Within a year of its conclusion, questions arose about salt taxation in Upper Burma, the debate between colonial administrators at various junctures revealing something of the nature of state power in these new domains of the British Empire, part of which consisted of a jungly upland frontier with China. Salt was both a necessity as well as a valuable item of trade and source of livelihood; as such, the state's efforts to control its flow into 'rebel' territories were a means of exerting political authority. ${ }^{38}$ The institution of prohibitions and blockades was part of the larger arsenal of punitive measures during the pacification campaigns that continued in postconquest Upper Burma into the 1890s much as in the Indo-Afghan frontier of the $1840 \mathrm{~s} .{ }^{39}$ Thus, a colonial officer at Kyaukse reported to his superior in nearby Mandalay in September 1886 that he had 'prohibited the export of salt eastward [into the Shan country] until dacoits rebels in that direction cease marauding. ${ }^{40}$ When the Government of India proposed in 1886

\footnotetext{
${ }^{36}$ Agha, 'Trans-Indus Salt', 24, 28-29; James Hevia, The Imperial Security State. British Colonial Knowledge and Empire-Building in Asia (Cambridge: Cambridge University Press, 2012), 213-13.

${ }^{37}$ Charles Crosthwaite, The Pacification of Burma (London: Edward Arnold, 1912), excerpted and reprinted as, Idem, 'The Administration of Burma' in South East Asia. Colonial History, ed. By Paul H. Kratoska (London: Routledge, 2001), here 217.

${ }^{38}$ Reflexively, efforts to control the country contributed to knowledge about it, including its trade. J.G. Scott, then Superintendent of the Northern Shan States, authored 'The Pacification of the West Mang Lün with Notes on the Wild Wa Country' in June 1893 while at Lashio, within which he notes the routine barter of opium, walnuts, and other wares obtained by the Möng Maü people for the rice and salt available in the valley settlements. The report is published in: Reports on Wa State by British Officers during the Colonial Period - II (Rangoon?: Archives Dept., 1980?), of which 19-20 for the above details. Note: the Wa States were also known as the Gold Tracts, as Wa Pet Hken and Mong Lem, or else as the northern cis-Salween States of Hsi Paw and North and South Hsenwi. ${ }^{39}$ Crosthwaite, Pacification of Burma, passim.

${ }^{40}$ NAM, Upper Burma, Forest Department, 1886, 558, 2228, 2.
} 
that the salt tax be 'raised to [the] Bengal rate' on account of the 'people there pay[ing] very little', the local officer, Major Cooke - perhaps more aware than his predecessors stationed on the Indo-Afghan frontier some decades earlier - replied: 'at present, and until Upper Burma is quieter, I cannot propose a new tax such as salt on any part of the country. ${ }^{24}$

To be sure, taxation of the production, trade, and consumption of salt were each a valuable and important source of revenue. ${ }^{42}$ To this extent, the local officer's discretionary prohibition - as punitive measure - of the salt trade into the Shan country and onward to China was soon repealed, for '[i]t scarcely seems desirable to do anything which stops trade with Shan States unless the advantage to be gained is great. ${ }^{43}$ That said, dependence on salt trade was some tribes' Achilles heel, so that cutting off their access to salt remained a part of the colonial administrator's arsenal of coercion. The Kachin, for example, were important buyers of salt from valley markets since there was 'so little salt in Kachin land that an offer of it' was deemed 'most acceptable', and the commodity was similarly a form of currency in the southern Wa states. ${ }^{44}$ Thus, '[h] $\mathrm{h}$ undreds of Kachin [highlanders] may be seen each year walking to Myitkyina, Mogaung, or Kamaing for their annual supply of salt', which was sold by the later nineteenth century by Chinese or Indian dealers. ${ }^{45}$ In consequence, frontier officers were advised that, were the Kachin 'tribesmen from unadministered territory [to] become hostile before their annual supply of salt has been secured,' then 'an effective way of checking them will be by forbidding their entry to the salt markets.' 46 While the state's brute force was thus

\footnotetext{
${ }^{41}$ NAM, Foreign Department, Political, 1886, No. 66, 1856, citations 3 and 4, respectively.

${ }^{42}$ Yet, despite its importance, the tour of the Government of India's salt inspector did not extend to Burma, his report relaying only second-hand information from that province: IOR/V/27/324/3: Report on the System of Weighing Salt in Bengal, Madras, Bombay, Sindh, Northern India, and Burmah (Calcutta: Government Printing, 1890), here p. 24.

${ }^{43}$ NAM, Upper Burma, Forest Department, 1886, 558, 2228, citation 4 and notice of repeal of the prohibition on 9.

${ }^{44}$ W. J. S. Carrapiett, The Kachin Tribes of Burma. For the information of Officers of the Burma Frontier Service (Rangoon: Government Printing and Stationary, 1929), 26 for citation, and 89 for the few sources of salt in Kachin territory; G. H. H. Couchman, Report of the Intelligence Officer accompanying the Superintendent, Northern Shan States, on his Tour in 1896-97 (Rangoon: Government Printing, 1897), 34.

${ }^{45}$ Carrapiett, Kachin Tribes, 9 and citation 88-89.

${ }^{46}$ Ibid, 89.
} 
built upon its control of access to salt, the archive also reveals, reflexively, colonial officers' understanding that legitimate authority derived from the fulfilment of the state's obligations to the populace, evident in traces of their reluctance or even resistance to instituting a new regime of salt taxation. At the same time, the idiosyncrasies and exceptions within the exertion of the government's salt monopoly in Burma - especially Upper Burma - highlight the challenges to the effecting of its sovereignty in practice and the lumpy topography of its power.

Published in 1910 for the aid of British civil servants arriving at their postings in Burma, The Burma Salt Manual contained excerpts of a sequence of legislation pertaining to the government's salt monopoly, thus also standing as testament to the importance of the latter. ${ }^{47}$ This legislation was comprised of government acts (the 1876 Lower Burma Land and Revenue Act, the 1882 Indian Salt Act), associated regulations (the 1889 Upper Burma Land and Revenue Legislation, which mirrored its 1876 precedent), and discretionary rules passed in keeping with these laws (most importantly, the 1910 Burma Salt Directions), as well as amendments. The 1876 and 1889 legislation specified that the state 'might make rules to grant (annual) licenses for the manufacture of salt and to collect an annual sum from the licensee on the salt made and the plant in which it is manufactured, and can punish those (manufacturers, owns of manufactories, those storing salt) for contravention' thereof. ${ }^{48}$ The rules were specified in 1887 and 1892: applications for licenses - stating, where relevant, the number and size of pots and iron cauldrons for the boiling of brine - were to be presented via village headman to the Township Officer (in Lower Burma) or the Assistant Collector (in Upper Burma), who would decide whether to grant or refuse the license, and the method of payment of the revenue in lieu.

\footnotetext{
${ }^{47}$ IOR/V/27/824/26: The Burma Salt Manual (Rangoon, Government Printing, 1910).

${ }^{48}$ Ibid, citation on 2 , and 13 .
} 
In Lower Burma, on the Irrawaddy Delta, local district commissioners had reported in 1888 to government on the nature and organisation of salt manufacture and the fees they thought most appropriate. This consultation was in light of a proposed increase in excise duty on each maund (equivalent to 82.3 pounds avoirdupois) of salt from 3 annas to 1 rupee, the intention of which was to bring policy into line with the requirements of the 1876 Act. The district commissioner (DC) for Bassein first reported there were no cauldrons, later offering a recommendation of five rupees per pot, based on the outturn of salt from a standard-sized boiling pot of sixteen maunds (or 360 viss). ${ }^{49}$ The Chief Commissioner quibbled with the language of the regulation, arguing that an increased tax on the 'quality of salt manufactured' would lead to a reduction in the quality of output, while also emphasising the need to account for the cost of labour and duty in the calculus of license-holders' decision to (legally) manufacture salt. The DCs of Henzada and Myangmya took the point further, both arguing that the industry would be abandoned if the suggested rates were introduced, the former noting that little salt was manufactured in villages from the saltlicks at the foot of the Western Yoma (the Arakan Mountains) and scarcely met local requirements, not least because firewood had to be cut and brought to the saltlicks, so that the boiling pots were only worked for half the month. The Henzada DC thus thought a large increase would prove ineffective, whereas the Myaungmya DC recommended raising rates to Rs.2/pot and Rs.10/cauldron. ${ }^{50}$

The Financial Commissioner for Burma thus concluded that, since 'many salt manufacturers are unable to pay half the amount due for their licenses before the license issue', it might be desirable to issue the licenses with payment 'recoverable in such instalments as may be decided upon after the manufacture of salt has commenced.' ${ }^{51}$ The Chief Commissioner duly instituted the sale of licenses for salt manufacture through thugyi (headmen) of the village

\footnotetext{
${ }^{49}$ NAM, Office of the Commissioner Irrawaddy Division, Finance Department, Excise, 1888, 17E4, 8486, 8.

${ }^{50}$ Ibid, 10-11, 45, 59-60.

${ }^{51}$ Ibid, 62-63.
} 
circle to the township officer, who would decide on whether to grant the license, and for which payment would be recovered in two instalments from December to the following June, the first once half the revenue had been earned. ${ }^{52}$ Yet, the negative repercussions of the new policy were soon relayed to government. From Thongwa district came notice in October that the increased salt duty would seriously hurt the trade in ngapi, fermented fish paste, for fifty fewer boats would go out to catch fish due to prohibitive cost of salt so crucial to its manufacture. So important is ngapi to Burmese cuisine, that a substitute article from Singapore made with lessheavily taxed (and thus cheaper) salt was expected to command the market. ${ }^{53}$ Such complaints suggest the cost of the extra tax was passed to consumers. From Bassein district came more than reports of many giving up salt production because of the burden of the new rates; a petition of November 1888 from 'Maung Kyaw Hla and 17 other residents of Ngaputaw Township and Maung Shwe Tsoe and 16 others against the enhanced rate of salt duty' called for the removal of the new rates since manufacturers could not pass on the added cost to consumers in the face of cheap salt from Europe, already preferred - they claimed - because of its market price, adding that these costs would also effect ngapi production, thus wiping out effecting the livelihoods of salt manufacturers as well as fishermen and makers of $n g a p i{ }^{54}$ In light of such evidence, it was decided to maintain the rate of salt duty in place prior to the coming into force of the 1876 legislation..$^{55}$

In these responses, therefore, can be seen the conflict between the imperatives of the central state and its representative with his ear to the ground in the locality, the latter's trepidation about interfering with salt taxes reflecting at least tacit recognition that salt

\footnotetext{
52 Ibid, 64.

${ }^{53}$ Ibid, 70-71.

${ }^{54}$ Ibid, 56-57, 75, 87-88. The Financial Commissioner later suggested that locally-manufactured salt was held in higher esteem than imported salt, although it is not clear whether this included European salt or accounted for regional variations in preferences: NAM, Office of the Commissioner Irrawaddy Division, Revenue Department, 1891, 7SL, 13081, 2. Most of the European salt was from Liverpool at first, before being superseded by German salt, as discussed below.

${ }^{55}$ This was revised in 1894, when a duty of six annas per maund of imported salted fish was levied; Report on the Administration of Salt Revenue [...] 1897, 2.
} 
possessed a critically-important place in the expression of sovereignty in monsoon Asia. The whole question of altering salt taxes - not least in Upper Burma immediately after annexation, when the state's authority was most fragile and fiercely contested - was emblematic of the fine balance between a ruler's prerogatives and his duties to his subjects. Yet, the manner of assessment and collection of revenue, which was based on either of two systems, reveals a different problematic of state power. One system was direct duty, operational where the government possessed sufficient powers of surveillance and enforcement, generally because production was large-scale and concentrated near population centres; this was common only in Lower Burma. ${ }^{56}$ Otherwise, the 'composition system' - combining the license fee and charges based on guestimates from assessment of the pots and cauldrons of the outturn of salt - was in force, which was the norm in Upper Burma where the productive scale was smaller and population more dispersed and distant from the state's official presence (Figure 2). ${ }^{57}$ Adjudicating the appropriate level of composition - appropriate to maximise fiscal receipts without a tax revolt - proved vexatious for the state, with the 1888 rates revised upward in $1889,1890,1895$, and twice in $1897 .{ }^{58}$ The very necessity of the composition system, not to mention all its complexities, reflected at once the limited reach of the state into the indigenous economy and the obstacles to the former's rationalising impulses; for, in place of modern or uniform productive technologies, methods, and establishments that were easily taxable, there was instead a chaos of multitudes and the ever-present feeling that the 'cunning natives' were evading the state's fiscal authority and its revenue demand by muddling information about the size of their operation. Intermediating through the services of local headmen was one means of strengthening the state's position, but the challenges of revenue collection remained formidable, and reflected the spatial variations in colonial power. In Lower Burma, headmen

\footnotetext{
${ }^{56}$ For the strict rules by which salt subject to direct duty was to be stored, weighed, and so forth: Burma Salt Manual, 42-44.

${ }^{57} \mathrm{Ibid}, 5$ and $17-18$.

${ }^{58}$ Report on the Administration of Salt Revenue [...] 1897, 1-2.
} 
received 5 per cent up to Rs.6000-worth of collections and 2.5 per cent on amounts above that. ${ }^{59}$ In Upper Burma, where the colonial administration was thinner and its reach into local society weaker, they received 10 per cent of all collections. ${ }^{60}$ In the latter, furthermore, township officers were spared the requirement of monthly supervisory visits to saltmanufacturing centres, for quarterly or even yearly visits were more practicable. ${ }^{61}$

Figure 2

\begin{tabular}{|c|c|}
\hline District & Rates \\
\cline { 1 - 1 } Minbu & Rate/earthen pot or bowl-shaped iron cauldron of from 2 to 2.5 gallons \\
capacity, Rs.5.
\end{tabular}

\section{Extract from 'Memorandum by the Financial Commissioner on Salt Excise in Burma' detailing Rates on Salt Production in Upper Burma ${ }^{62}$}

The Indian Salt Act of 1882 was instituted in Upper Burma by legislation of 1889 and 1891, which specified that 'from time to time by rule,' government might 'prohibit absolutely, or subject to such conditions [...], the manufacture of salt'. ${ }^{63}$ One reason in favour of prohibition in Burma related to the peculiarities of its economy; namely, the transformation after 1852 of the wet zone into one of the world's largest rice-producing regions. ${ }^{64}$ By the close

\footnotetext{
${ }^{59}$ Burma Salt Manual, 40.

${ }^{60} \mathrm{Ibid}, 41$.

61 IOR/V/24/3934: Report on the Administration of Salt Revenue in Burma for the Year 1901 (Rangoon: Government Printing, 1902), 1.

${ }^{62}$ NAM, Office of the Commissioner Irrawaddy Division, Revenue Department, 1891, 7SL, 13081, 2.

${ }^{63}$ Burma Salt Manual, 24.

${ }^{64}$ Willem Van Schendel, 'Origins of the Burma Rice Boom, 1850-1880' Journal of Contemporary Asia, vol. 17 , no. 4 (1987), 456-72.
} 
of the nineteenth century, British colonial policy in Burma was geared toward the logic of the rice economy: everything, from policing disorder to the racialised policy of opium sales and consumption, was connected to the requirements of labour and the maintenance of an order practically built on mono-commodity production. ${ }^{65}$ In this context, as revealed by the responses collated into a 'Memorandum by the Financial Commissioner on Salt Excise in Burma' of 1891, some district commissioners viewed the effect of higher rates on locally-manufactured salt not as killing off an industry but as incentivising people to take up rice cultivation 'more vigorously', the priority in the well-watered lowlands, thereby returning salt production to its prior size and scale. ${ }^{66}$

Others, however, were more sympathetic. In light of recent experience, DCs in Lower Burma reiterated many of their older concerns about further interference. In the main, however, sympathy with local populations arose most prominently in 1891 from those representing districts in Upper Burma, where rice cultivation was of much less significance to the economy, compared to sesame and a few other crops, and where the populace were more sensitive to policy changes because of the prevalence of subsistence agriculture, especially in the uplands. ${ }^{67}$ From such districts came the criticism that a duty of one rupee per maund was regressive, hurting smaller producers, including those individuals who were captured within the state's fiscal net - despite producing for private consumption yet charged at the same rates as professional salt manufacturers - because assessment took place during the agricultural slack season (February-May) when they were operative, as well as extracting proportionally more revenue from those operating at lesser output efficiency for their scale and those facing higher costs of fuel and other inputs. ${ }^{68}$

\footnotetext{
${ }^{65}$ Saha, Law, Disorder and the Colonial State; Wright, Opium and Empire.

${ }^{66}$ NAM, Office of the Commissioner Irrawaddy Division, Revenue Department, 1891, 7SL, 13081, 15.

${ }^{67}$ Myint-U, Making of Modern Burma, 142.

${ }^{68}$ NAM, Office of the Commissioner Irrawaddy Division, Revenue Department, 1891, 7SL, 13081, 2.
} 
Pragmatism, however, was the main motivation for outlawing domestic manufacture, for it necessarily entailed the import of foreign salt in substitute, which was deemed preferable because it was easier to tax - especially when compared to the highly idiosyncratic composition system - and increased control over revenue capture, although coastal smuggling and illegal salt production were obvious (and persistent) problems. ${ }^{69}$ Pragmatism also led to further complexity and ambivalence, overall. Prescribed by the Financial Commissioner in 1910, the Burma Salt Directions specified where domestic manufacture would be maintained, designated by (a) if relating to a district under the direct duty system or (b) if the composition system was in force: 'Kyaukpyu (a). Myaungmya (a). Tavoy (a). Thaton (b). Katha (b), Hanthawaddy (a). Bassein (a). Amherst (a). Mergui (a). Sagaing (b). Shwebo (b). ${ }^{70}$ The Burma government had earlier expressed varying opinions about whether to kill off local manufacture gradually or as in the Tenasserim, Pegu, and Irrawaddy divisions - 'with a blow'. ${ }^{71}$ The 1910 regulations specified a combination of approaches. In Akyab, Minbu, Sandoway, and Meiktila, where the cumbersome composition system was in force, 'the industry is to be suppressed gradually by the refusal to grant licenses to new applicants or to the heirs of deceased licensees. ${ }^{72}$ In Pakokku, Lower Chindwin, Yamethin, Magwe, Upper Chindwin, and Myingyan districts, where salt taxation was also subject to the composition system, 'immediate suppression is not insisted on, [but] officers are to bear in mind the expediency of discouraging the industry' ${ }^{73}$ Where the salt industry had ceased to exist, officers were not to issue new licenses so that the industry would not be revived. ${ }^{74}$ Only in the wake of Gandhi's salt satyagraha in 1930 was some relief given to the poor living in or near the saline tracts, who were - by the Delhi

\footnotetext{
${ }^{69}$ Note: the extent of contraband operations is discussed in each of the annual reports on the administration of salt revenue examined and discussed here.

70 Burma Salt Manual, 37.

71 IOR/V/24/3934: Report on the Administration of Salt Revenue in Burma for the Year 1900 (Rangoon: Government Printing, 1901), i.

${ }^{72}$ Burma Salt Manual, 37.

${ }^{73}$ Ibid, 38.

${ }^{74}$ Ibid, 38, for the list of districts.
} 
Concession of 1931, part of the larger Gandhi-Irwin Pact aimed at ending the civil disobedience of the previous year - allowed to manufacture salt for their own use, although this fell short of the Mahatma's demand for the total dismantling of the salt tax and monopoly in British India. ${ }^{75}$

How, around the turn of the century, were the effects of these shifts in policy felt in (Upper) Burma? The prices of foreign salt in interior Burma were said to be entirely dependent on the Rangoon market, but trade upriver into Upper Burma grew nonetheless. ${ }^{76}$ On the one hand, if domestic production was shrinking as a result, then the consumption of Burmese salt would also decline. At the turn of the century, locally-made salt was thought to have 'little or no influence on the Upper Burma market'. ${ }^{77}$ One exception was the salt of Shwebo (and Sagaing), which was produced both from private and the former royal wells, the surpluses sold within Upper Burma and sent to Bhamo for what the British called 'transfrontier' trade. ${ }^{78} \mathrm{~A}$ decade later, Burma salt still constituted 32 per total consumption. ${ }^{79}$ Although this included Lower Burma's consumption, it nevertheless demonstrates that hopes for imported salt supplanting domestic manufacture - and the effects of policy to curtail the latter - had not fully materialised ${ }^{80}$ And, furthermore, in Burma's 'princely states' - the 'unadministered' polities in the uplands, where the Burma government's state's reach was practically and legally most limited even as it claimed suzerain authority - there was at least one instance of newfound or

\footnotetext{
${ }^{75}$ For discussion of the effects of this policy in Burma, including the feeling - and resultant efforts - of the state to detect where individuals were 'abusing' the new policy: IOR/V/24/3935: Report on the Administration of Salt Revenue in Burma During the Year 1934-35 (Rangoon: Government Printing, 1936), 11.

${ }^{76}$ Report on the Administration of Salt Revenue [...] 1897, 2-3.

77 IOR/V/24/3934: Report on the Administration of Salt Revenue in Burma for the Year 1898 (Rangoon: Government Printing, 1899), 2.

${ }^{78}$ On production in Shwebo and Sagaing, in addition to details in Figure 2. above, see: NAM, Office of the Commissioner Irrawaddy Division, Revenue Department, 1891, 7SL, 13081, 2; IOR/V/24/3934: Report on the Administration of Salt Revenue in Burma for the Year 1899 (Rangoon: Government Printing, 1900), 2. The composition rates were higher than elsewhere, probably indicative of larger pots or cauldrons as necessary for larger-scale production (i.e., for sale in proximate markets): Burma Salt Manual, 18-19.

Other reports indicate that Bhamo's import of Shwebo salt for onward trade was quite modest, contributing only 110 maunds of a total of 36,210 maunds - for purchase by Shan and Kachin tribes as well as onward trade - in 1900: Report on the Administration of Salt Revenue [...] 1899, 5.

${ }^{79}$ IOR/V/24/3934: Report on the Administration of Salt Revenue in Burma During the Year 1909 (Rangoon: Government Printing, 1910), 3.

${ }^{80}$ For a statement of the perception that Burmese had steadily been switching to imported salt over the final three decades of the century: Report on the Administration of Salt Revenue [...] 1897, 3.
} 
newly flourishing enterprise: the Bawgyi salt wells of the Northern Shan States, outside the jurisdiction of the colonial state's fiscal regime because of the sawbwa's (the Shan hereditary ruler) autonomy over their domestic policy, where output doubled in the mid-1900s. ${ }^{81}$ On the other hand, a corollary of the fiscal regime and prohibition would be substitution of Burma- for foreign salt, specifically Liverpool salt, which was commanding a growing share of the market up to the turn of the century - and another instance of how the colonies supported the metropolitan economy. This was surprisingly profitable despite the distances involved because salt was used as ballast, so that transportation costs to the port at Rangoon were negligible. Even here, however, all did not continue to plan: 'Liverpool salt appears to have lost its former position in the Burmese market', it was reported in 1910, 'and to have been supplanted by the inferior German salt. ${ }^{, 82}$ Gradually, other kinds of salt also appeared on the Burma market, including that imported from Port Said and Aden, whose share steadily increased through the following decade and contributed to the further deterioration of the position of English salt in Burmese consumption. ${ }^{83}$

\section{III}

Salt was so important to human life in hot and humid monsoon Asia, that the manufacture and taxation of salt, as well as control of supply through regulation and licensing, were not only vital to the state's fiscal health but also imbricated in the everyday expressions of its sovereignty. So obvious and ubiquitous, in fact, that historians have only brushed past - but never paused to carefully examine - its place in the social life of the state. This article has highlighted that salt was critical to the compact forged between sovereign and subjects in India

\footnotetext{
${ }^{81}$ IOR/V/24/4256: Note on the Transfrontier Trade of Burma, 1906-07 (Rangoon: Government Printing, 1907), 1 , where it is also recorded that the colonial state had no idea whether or how much duty was levied.

${ }^{82}$ Report on the Administration of Salt Revenue [...] 1899, 13.

${ }^{83}$ Report on the Administration of Salt Revenue [...] 1909, 6; IOR/V/24/3935: Report on the Administration of Salt Revenue in Burma During the Year 1922-23 (Rangoon: Government Printing, 1923). In turn, these changes subtly transformed trade across the frontier, which is the subject of forthcoming work by the author.
} 
and China, for example, then closely focussing on colonial Burma to reveal the processes through which the state effected is authority, how the compact was forged with its subjects, and how local circumstances changed the balance of power between the two parties in the negotiation of obligations and rights. To do so, it has examined the period of colonial rule commencing from the establishment of the Government of India's salt monopoly, which was enacted around the same time as the final stage of the conquest of Burma. But one moment in Burma's history, toward the end of the colonial period, captures much of the essence of what has been described above.

A few years after Burma's divorce from India, the British Empire faced its greatest cataclysm: war in Asia. The destruction brought by the bombing of Rangoon is palpable even today, for the burning of government offices decimated the colonial archive, its yawning gaps and silences a reminder of the Japanese conquest and occupation. ${ }^{84}$ The disruptive - if not also destructive - effects of warfare were much farther-reaching, however, and the Upper Burma frontier with China was no exception, for Yunnan province played a pivotal role in Chinese pushback against Japan. By winter 1944, the tide turned against the Axis forces as the Allied powers began the reconquest of Japanese-occupied Burma. Preparations for victory were already in motion earlier that summer, however, following successes against the Japanese. At 10am, Friday 9th June 1944, the Consultative Committee of the Burma Government had met during its exile in Simla, India, for its third meeting. Its dedicated topic of discussion: the 'Report of the Expert Advisory Committee on the Rehabilitation of the Salt Industry'.

Burma's salt industry had not been destroyed by colonial policy before the war, in fact continuing to meet around half of domestic demand. The remainder was largely fulfilled by German salt, although German shipments met significant competition immediately before the

\footnotetext{
${ }^{84}$ For a general history: Christopher Bayly and Tim Harper, Forgotten Armies. Britain's Asian Empire and the War with Japan (London: Penguin, 2005).
} 
outbreak of war from Karachi, from whence were transported significant quantities of salt Indian, thus not subject to protective duty - to Rangoon. ${ }^{85}$ But there was (conflicting) evidence of shortages by 1944 , with high prices and the introduction of rationing serving as indications of a maldistribution (if not the outright scarcity) of salt, and the Committee also needed to consider the possibility that 'the salt industry might be entirely dislocated by military operations for the recovery of Burma and the destruction of plant by the enemy prior to his withdrawal. ${ }^{86}$ At the same time, resuming importation of German salt was obviously off the table, while procurement from other places around the Indian Ocean was likely to be challenging until the cessation of the war. Ultimately, if Britain was to successfully take enemy-occupied Burma: 'The vital need which Burma has for a reasonably assured salt supply, whether from local production or from import, requires no stressing. ${ }^{97}$

The Committee thus discussed each item in the report, paying attention to the immediate and longer-term issues at stake in returning Burma to at least its pre-war level of self-sufficiency, including the seasonality of productive operations and its implications for the salt deficit and stockpiling; the nature of government encouragement or intervention in what were essentially private enterprises; when (or whether at all) taxes should be levied, and at what rates, as excise and on imports; the price and necessity of government monopoly on sales, in the first instance and possibly beyond; and the role of the military in distributing supplies to civilians. A final consideration was the extent to which the salt wells of Upper Burma should be exploited, lest they dry up, or production concentrated in the salt fields of Amherst district (prior to the war, contributing around eight-tenths of Burma's total output), with the risk that resultant demand for locally-available fuel for the boiling operations denude the surrounding

\footnotetext{
${ }^{85}$ IOR/M/3/1421: 'Rehabilitation of the Burma Salt Industry', F.D. Odell (Secretary for Agriculture and Rural Economy), 27.12.1944.

${ }^{86} \mathrm{IOR} / \mathrm{M} / 3 / 1421$ : 'Memorandum', 9.6.1944.

${ }^{87}$ IOR/M/3/1421: F.D. Odell, the Secretary for Agriculture and Rural Economy, to the His Excellency the Governor of Burma, Colonel Sir Reginald Hugh Dorman-Smith, 27.12.1944.
} 
forests. ${ }^{88}$ The colonial state was thus carefully planning how it would entirely re-establish itself, a task in which control of the production and distribution of salt was as critical as it had been in the 1880 s or 1910 s. This control had to be durable, furthermore, with the Committee as attentive to exigencies in the short-term, as matters effecting the longevity of the colonial state's political authority.

By focussing on this material substance, this article draws the study of the law and state power into dialogue with matters of political economy, material life, and the environment. ${ }^{89}$ It also contributes to a growing (albeit disparate) body of work that examines the power of the state not solely or primarily through the actions of human agents and the ideologies or institutions of their creation, including those relating to crime and punishment. Instead, the state is viewed in such work through the lens of non-human actors, including commodities, animals, and even the natural environment, or else the way these have moulded the character of governance and power. A few pertinent examples from monsoon Asia may suffice to give a sense of this field. A number of historians have lately demonstrated how the gendered, raced, and classed hierarchies at the heart of the British imperial project were disrupted by non-human animals and the difficulty of human-animal relationships. ${ }^{90}$ Mosquitoes are a prime example, although there were spaces - such as the Burma-China borderland - where indigenes were more resistant to malaria than outsiders, whether the latter were drawn from among the

\footnotetext{
${ }^{88}$ H.L. Chibber, 'The Salt Industry of Amherst District' in The Journal of the Burma Research Society, vol. xix, no. 2 (1929), 47-56, of which the analysis on 52 and plates II-III demonstrate Amherst's significance as well as the impact of the Great War years on dramatically - albeit temporarily - enlarging output, and 54 for discussion of the reliance on moneylenders and its (negative) impact on profits in turn that the author of this article has not seen discussed elsewhere.

${ }^{89}$ Rohit De, A People's Constitution. The Everyday Life of Law in the Indian Republic (Princeton: Princeton University Press, 2018), is but one brilliant recent example of an emerging wave of scholarship that similarly understands the state and sovereignty not as abstracts to be understood through the study of political and legal thought (and their instantiations), but as practices whose content and character was fleshed out in the quotidian often, material or commercial - realm through everyday encounters.

${ }^{90}$ Antoinette Burton and Renisa Mawani, eds., Animalia: An Anti-Imperial Bestiary for Our Times (Duke University Press, 2020), for a wide range of scholarly perspectives from across the British Empire.
} 
colonised or from the expatriate population..$^{91}$ Erica Mukherjee has recently illuminated how the riparian landscape of the Ganges delta frustrated the late eighteenth-century colonial state's effort to institute a new political economy in Bengal. In theory, settling in perpetuity the tax demand made of proprietors of land would turn them into the 'improving' landlords of Enlightenment political thought that informed East India Company policy, for rational actors would recognise the incentive to make their landholdings more productive and thereby realise greater profit. In practice, the nature of local rivers was such that alluvium was eroded from one place and brought to another, so that the landholdings underpinning the so-called 'Permanent Settlement' of 1793 were in many places fundamentally impermanent, undermining the stimulus to natural improvement and precipitating bankruptcy and unrest. ${ }^{92}$

While contributing to the broader methodological shift represented by such scholarship, there is, nevertheless, something singular and distinctive about the present analysis. Salt was critical to the consumption of the entire populace - indigenous and expatriate, rich and poor, military and civilian - everywhere across colonial Burma. Its absolute necessity was the basis of the compact forged between ruler and ruled, reminiscent of E.P. Thompson's notion of a 'moral economy' of reciprocal rights and obligations between the ordinary folk and their masters. ${ }^{93}$ Except, as this analysis has demonstrated, the spread of industrial capitalism - here represented by imported salt from England and Germany - did not quite eradicate and replace this archaic and patrimonial relationship with an abstract, impersonal, and more modern one, as Thompson supposed. ${ }^{94}$ Salt's very mundanity is also distinct, and a focus upon this commodity has brought to attention how deep, insidious, and potent was the everyday power

\footnotetext{
${ }^{91}$ David A. Bello, 'To Go Where No Han Could Go for Long: Malaria and the Qing Construction of Ethnic Administrative Space in Frontier Yunnan' Modern China, vol. 31, no. 3 (2005), 283-317.

92 Erica Mukherjee, 'The Impermanent Settlement: Bengal's Riparian Landscape, 1793-1846', South Asian Studies, vol. 36, no. 1 (2020), 20-31.

${ }^{93}$ E. P. Thompson, 'The moral economy of the English crowd in the eighteenth century' Past and Present, no. 50 (1971), 76-136.

${ }^{94}$ Around the same time as Thompson, the idea of 'moral economy' was used to explain anti-colonial protest in Burma in a now classic work: Scott, Moral Economy.
} 
of the state able to control its production or consumption. By the same turn, it has also been shown how very fragile the state's authority was in those places where its control was weaker or more difficult to effect - a point that brings to attention a larger set of arguments made in this article about territory.

By venturing from the delta to Lower Burma at large, and from thence to Upper Burma and the frontier, it is clear that the ambivalence of colonial administrators and the exceptions or idiosyncrasies written into the law were the product of very real constraints: epistemological and material, environmental and demographic, and of personnel. This is amply reflected in the higher rates of reward for indigenous intermediaries in Upper Burma compared to Lower Burma that was not an aberration or abuse but, in fact, enshrined in the very substance of the law (i.e., the Burma Salt Directions of 1910). The nature and persistence of the composition system, complete with all its manifold variations, as well as the difficulty outside the delta and especially in Upper Burma - of prohibiting salt manufacture to precipitate the necessity of export, is all evidence of the obstacles to the government's most fulsome exploitation of its salt monopoly. The sovereignty of the Burma government was thus contested from the ground up, forged as a negotiation between the centre, the districts, and their populations, to produce an expression of power that was not only layered - that is, direct in some places but effected, if at all, through suzerains in others - but also spatially-variegated and lumpy.

The 'ability to create exceptions has always been held to be a norm of sovereignty', Rohit De says of legal scholars' (including historians') understanding of the state and its law. ${ }^{95}$ One site that has been critical to thinking about legal exception in the British Empire has been the borderland or frontier. ${ }^{96}$ On the imperial periphery were found those non-sedentary populations described by contemporaries as 'savages', violent 'tribals', and other 'wild' or

\footnotetext{
${ }^{95}$ De, $A$ People's Constitution, 52 for citation.

${ }^{96}$ See, above: n. 32.
} 
'uncivilised' people bonded by kinship ties and the supposedly timeless precepts of 'custom' and 'tradition' into collectivities. ${ }^{97}$ One view, proposed by James Scott and others, is that such peoples had historically moved into the inhospitable and unproductive uplands ('Zomia') to escape and seek refuge from the predation and coercion of modern states sited in the plains. Upper Burma and its highlands have been central to Scott's work, which has since been extended to other hilly and mountainous borderlands around the world. Others have argued that Scott's thinking is flawed, for it ignores the long-standing interdependence of uplanders and lowlanders of the sort presented in this article. ${ }^{98}$ Others still, as exemplified by the recent work of Benjamin D. Hopkins, suggest that the aforementioned ideas about territory (the 'frontier') and its inhabitants ('savages') were the product of the expansion of modern states.

'They were not frontiers because of place,' Hopkins argues, 'but rather because of [...] the practice of administration that states used to govern them', which he calls 'frontier governmentality. ${ }^{99}$ As states expanded, they sought not to conquer and assimilate, but to physically and culturally contain and enclose this space - now discursively constructed as the frontier - and the indigenes who dwelt there. As the state was weakest on the frontier, it sanctioned certain groups to rule on its behalf with reference to local 'customs' and 'traditions' of their own definition and in a highly personalistic form of rule, which was 'another form of subjugation and governance rather than the absence of it', not least because this procedure involved privileging certain groups (for instance, the elite men of particular tribes) over others. ${ }^{100}$ A centrepiece of Hopkins' analysis is the Frontier Crimes Regulation (FCR) that was promulgated in 1872 to deal with the problem of violence on the Indo-Afghan frontier, and which went on to become a role model of frontier governmentality in Palestine and Iraq, in

\footnotetext{
${ }^{97}$ Benjamin D. Hopkins, Ruling the Savage Periphery. Frontier Governance and the Making of the Modern State (Cambridge, Mass.: Harvard University Press, 2020), 2-3 and passim.

98 See, above: n. 26

${ }^{99}$ Hopkins, Ruling the Savage Periphery, 5.

${ }^{100}$ Ibid, 7.
} 
Nigeria, Kenya, Somalia, and South Africa. Although mentioned only briefly, Hopkins notes that variations of the FCR were hastily rolled out over Upper Burma in the 1890s in the form of statutes governing the Kachin Hills (1895), the Chin Hills (1896), and the wider Burma Frontier Tribes Regulations (1896). ${ }^{101}$ This ought not be surprising given the evidence presented in this article. Those methods of conquest, pacification, and coercion deployed in Upper Burma that rested on control of access to salt, as a ready necessity, were first perfected on the Indo-Afghan frontier, for colonial officers - many of whom had cut their teeth on the Northwest Frontier of British India- saw a similitude between the landscape and peoples of these two places, and thus of the strategies there most likely to succeed.

Though his work does much to dismantle the core-periphery understanding of territory that remains ingrained in the historiography of states and empires, Hopkins' analysis inadvertently relies on the discursive binaries of civilised and uncivilised, the assimilated core of the modern state and its unassimilated frontier. By shifting focus from the study of exceptional laws and arbitrary powers in unusual spaces (such as 'frontiers'), and instead looking at everyday aspects of the state and its spatial variations across the state as a whole, this article offers a more complex picture. British Burma was composed of multiple distinct spaces. On the one hand, there was the heartland or core of the colonial state on the Delta. On the other, there were the unadministered 'princely states' (the Shan States, for instance), which were counterparts to the suzerainties of Indian maharajas in British India, as well as the administered tracts (such as the Kachin country), where exceptional laws were in place to govern the 'independent tribes', and which were conceived as analogues of the Northwest Frontier. Between these, however, was the heart of the Burma dry zone - a vast space, including population zones in proximity of the Irrawaddy, such as Shwebo and Sagaing. This was neither the core of the colonial state nor its frontier, and certainly not some kind of stateless 'Zomia'.

${ }^{101}$ Ibid, 56-57. 
This was the heart of the precolonial Burmese state, yet proved challenging for the colonial state to govern in the same manner as the Delta, for reasons that deserve more careful analysis than can be given over here. The Burma 'dry zone' is a space that has long been neglected, yet this article has begun to prise open its important place not only in the history of Burma, but of the British Empire, for its further study contributes to a more complex understanding of the varied topographies of imperial power. 